American University Washington College of Law

Digital Commons @ American University Washington College of

Law

Project on Addressing Prison Rape - Articles

Content Type

Spring 2008

\title{
Prosecuting Sexual Violence in Correctional Settings: Examining Prosecutors' Perceptions
}

Brenda V. Smith

Jaime Yarussi

Follow this and additional works at: https://digitalcommons.wcl.american.edu/prisonrape-articles

Part of the Criminal Law Commons, Criminal Procedure Commons, Human Rights Law Commons, and the Law Enforcement and Corrections Commons

\section{Recommended Citation}

Prosecuting Sexual Violence in Correctional Settings: Examining Prosecutors' Perceptions, 3 Criminal Law Brief 19 (2008).

This Article is brought to you for free and open access by the Content Type at Digital Commons @ American University Washington College of Law. It has been accepted for inclusion in Project on Addressing Prison Rape Articles by an authorized administrator of Digital Commons @ American University Washington College of Law. For more information, please contact kclay@wcl.american.edu. 


\section{American University Criminal Law Brief}

\section{Prosecuting Sexual Violence in Correctional Settings:Examining Prosecutors' Perceptions}

Brenda V. Smith

American University Washington College of Law

Jaime M. Yarussi

Follow this and additional works at: https://digitalcommons.wcl.american.edu/clb

Part of the Criminal Law Commons

\section{Recommended Citation}

Smith, Brenda V., and Jaime M. Yarussi. "Prosecuting Sexual Violence in Correctional Settings: Examining Prosecutors' Perceptions." Criminal Law Brief 3, no. 2 (2008): 19-28.

This Article is brought to you for free and open access by the Washington College of Law Journals \& Law Reviews at Digital Commons @ American University Washington College of Law. It has been accepted for inclusion in American University Criminal Law Brief by an authorized editor of Digital Commons @ American University Washington College of Law. For more information, please contact kclay@wcl.american.edu. 


\section{Prosecuting Sexual Violence in Correctional Settings:}

\section{EXAMINING ProseCUtors' PERCEPTIONS ${ }^{\dagger}$ \\ Brenda V. Smith* and Jaime M. Yarussi**}

\section{Introduction}

The Prison Rape Elimination Act of $2003^{1}$ (PREA) is the first piece of federal legislation, which expressly and exclusively addresses sexual abuse of persons in custody. Notwithstanding passage of the Act, there is clear belief, echoed by correctional leaders, that prosecutors are reluctant at best, and unwilling at worst, to prosecute cases of sexual violence in correctional settings. In order to gather information on prosecutor interest in and capacity to prosecute these cases, the National Institute of Corrections Project on Addressing Prison Rape at the Washington College of Law the (the NIC/WCL Project) collected data from state and federal prosecutors.

This article draws on that research and data to examine the perception that prosecutors are unwilling to prosecute cases of sexual violence in custody, discusses barriers to prosecution identified by prosecutors regarding investigating and prosecuting allegations of sexual abuse of persons under correctional supervision, and recommends tools to overcome those barriers.

\section{Background and Methodology}

\section{Background}

In 2000, the NIC/WCL Project began training highlevel correctional administrators on identifying, addressing, and investigating allegations of staff sexual misconduct with offenders. Each year eight training teams from different states fielded three-person teams composed of key correctional decision makers for the state or agency, e.g., sheriffs, wardens, commissioners, and heads of human resources, investigations and training. Relatively quickly, correctional leaders acknowledged that staff sexual misconduct was an important safety issue that agencies needed to address. However, strengthening investigations and sanctions remained challenging. While investigators and correctional administrators knew they had much work to do to improve investigations, they complained that prosecutors were unwilling to take cases to trial. As a result, often their only tool was termination of the employee in strong cases and allowing the employee to resign in others. ${ }^{2}$

After hearing for some time that investigations were fruitless because of a lack of prosecutorial interest in sexual violence against persons under custodial supervision, the NIC/WCL Project required each three-person team that attended its investigative training to include a state or local prosecutor. They believed this inclusion would create collaboration and help each - corrections leaders and prosecutors - understand the other's challenges in addressing sexual violence in custody. Segments of the training, Investigating Allegations of Staff Sexual Misconduct with Offenders, were specifically designed to identify the barriers to prosecuting cases of sexual abuse of individuals under correctional supervision and strategies for overcoming those barriers. ${ }^{3}$

While training eight prosecutors a year for each of the state teams was helpful to the states, the NIC/WCL Project sought to have a larger impact. Seeking to address the lack of information on prosecuting sexual violence in custody, the NIC/WCL Project sought, and was granted, funding from the National Institute of Corrections (NIC) to work with prosecutors to develop a report addressing the existing relationships between law enforcement, correctional professionals, and prosecutors in addressing and prosecuting cases of prison rape.

\section{Methodology}

The NIC/WCL Project used three methods to compile information for the report. First, it conducted a literature review in order to identify previously identified barriers to prosecuting cases of sexual abuse of individuals in custody. Second, a NIC/WCL Project consultant conducted telephone and in-person, one-on-one interviews of prosecutors from February to May of 2006. Finally, the Project conducted a series of focus groups with federal and state/local prosecutors.

\section{Literature Review}

The NIC/WCL Project reviewed five kinds of resources: (1) case law; (2) statutes; (3) government reports; (4) reports by advocacy groups; and (5) news stories. The literature review provided background on sexual abuse of individuals in custody and validated barriers that prosecutors later identified in interviews and focus groups. The literature review also assisted in drafting questions to be asked during interviews of individual prosecutors and during focus groups of federal and state/local prosecutors.

\section{Interviews}

An NIC/WCL Project consultant conducted both telephone and face-to-face interviews with state/local and federal prosecutors from around the country. Eight formal interviews and twelve informal interviews were conducted. The interviewees were selected based on the following criteria: (1) jurisdiction; (2) experience prosecuting sex cases; (3) experience prosecuting prison cases; and (4) referrals by other legal and correc- 
tional professionals in the field.

Interview participants were asked the following ques-

tions:

1. What is your experience in the area of prisons (prosecutions, sexual abuse, contract facilities)?

2. Why are allegations of sexual abuse of prisoners rarely prosecuted?

3. What barriers exist to prosecuting these cases?

4. What can be done to lift the barriers and improve the likelihood of prosecuting these cases?

5. What is the response of judges and juries regarding the sexual abuse of prisoners?

6. What about cases involving inmate-on-inmate sexual violence - are these cases successfully prosecuted?

\section{Focus Groups}

After holding a series of "breakout sessions" with prosecutors during NIC/WCL Project training sessions, it was apparent that group discussions with prosecutors would yield rich information on this subject. In the interest of reaching a greater population of prosecutors, the NIC/WCL Project held focus groups with federal and state/local prosecutors. The focus groups also generated discussions and encouraged the exchange of ideas between prosecu-
$[P]$ rosecutors may be reluctant to pursue prison sexual assault cases because they see their job as done after securing the conviction or because they do not view crimes that occur in confinement as part of their purview.
The Perception that Prosecutors Are Unwilling to Prosecute Cases of Sexual Violence in Custody

The perception that prosecutors are either reluctant or unwilling to prosecute cases of sexual violence in custody is wellfounded. Both government reports 5 and testimony by current ${ }^{6}$ and former prosecutors ${ }^{7}$ reveal that these cases present significant challenges in the current prosecution environment. First, these cases are not high profile, high value cases; they do not increase the stature of the prosecutor within his office and the community at large. In fact, prosecuting these cases could significantly weaken a prosecutor's standing in the community by making her appear to be soft on criminals. Additionally, in many jurisdictions correctional staff are sworn peace officers who, as alleged sexual offenders, are the same individuals that prosecutors must rely on to testify in their other criminal cases.

Second, unsympathetic victims, delayed reports of the assault, lack of physical evidence, poor investigations, and conflicting testimony in tors, which could not be accomplished through one-on-one interviews. Twenty-seven prosecutors attended the focus group meetings - seven federal and twenty state and local prosecutors. ${ }^{4}$

\section{Federal Focus Group}

The federal focus group consisted of seven federal prosecutors, two federal investigators and one federal victim services coordinator. The NIC/ WCL Project extended invitations to individuals based on recommendations from former prosecutors and the United States Department of Justice (DOJ). During the first session of the meeting, prosecutors identified their experience with prosecuting cases from correctional agencies with a focus on sexual assault and abuse. During the second session, prosecutors addressed issues of barriers to federal prosecution and tools available to overcome those barriers.

\section{$\underline{\text { State Focus Group }}$}

The state focus group consisted of nine state and local prosecutors. The NIC/WCL Project extended invitations to individuals based on recommendations from correctional practitioners and past participants of NIC/WCL Project trainings. Specifically, the NIC/WCL Project sent a request to its listserv for contact information of prosecutors who had either prosecuted these cases or were particularly helpful in getting these cases heard. The NIC/WCL Project received over twenty responses from correctional professionals across the country. In extending the final invitations, the NIC/WCL Project considered geo- these cases make them high risk cases. Prosecutors often measure their success by their wins. ${ }^{8}$ Sexual assault cases are notoriously hard to win. ${ }^{9}$ Custodial sexual abuse cases are even more difficult and expose prosecutors to the possibility of expending valuable cutorial success - either a plea or conviction.

Third, prosecutors often see their role as securing significant sentences for hardened criminals. Some may even believe that being assaulted, physically or sexually, is a part of the penalty for the crime. However, the more informed view is that prosecutors must ensure that individuals who are sentenced to imprisonment are in safe and secure environments. Either way, prosecutors may be reluctant to pursue prison sexual assault cases because they see their job as done after securing the conviction or because they do not view crimes that occur in confinement as part of their purview. ${ }^{10}$

Barriers to Prosecuting Prison Sexual Assault Cases

\section{Differences between Administrative and Criminal Cases}

One of the major barriers identified by both state and federal prosecutors is the difference in standards of proof required for discipline in administrative proceedings and the burden of proof that prosecutors must meet in criminal proceedings. In administrative proceedings, the standard of proof required by the person seeking the administrative action is generally "preponderance of the evidence."11 In criminal cases, prosecutors will only secure convictions if they prove each resources on a case that may not have a high likelihood of prose- 
element of an offense "beyond a reasonable doubt."12 Both Inspector General Glenn Fine and Senator Jeff Sessions discussed the lack of prosecutions in custodial sexual abuse cases in their testimony before the National Prison Rape Elimination Commission (NPREC). ${ }^{13}$ They both noted the importance of prosecutions, yet acknowledged the difficulty in bringing these cases. ${ }^{14}$ Each raised the standard of proof as one of the major difficulties in prosecuting prison sexual assault cases. ${ }^{15}$

\section{Staff Sexual Abuse of Offenders}

During focus groups held with state and federal prosecutors, attendees pointed out that proceedings to impose administrative sanctions often preceded criminal prosecutions in staff sexual misconduct cases. They agreed that this timing often creates a problem for criminal prosecutions. ${ }^{16}$

First, the burden of proof in an administrative proceeding is lower. If a staff member is successful in the administrative proceeding, it often implicitly discourages additional action in the criminal matter, given the lower burden of proof in administrative cases. Second, investigations that are conducted for purposes of the administrative proceedings can often taint later criminal prosecutions, particularly if the suspect employee is compelled to testify under threat of losing employment. Case law makes clear that, employee testimony secured under threat of firing is compelled and cannot be used in a later criminal prosecution. ${ }^{17}$ Finally, often correctional staff are allowed to resign, an administrative sanction, in lieu of being criminally prosecuted for sexual abuse with persons in custody. Prosecutors generally recognize that with the burden of proof so high for a criminal case, administrative sanctions will be the most likely outcome in many cases and thus recommend harsher administrative penalties as a substitute for prosecution. ${ }^{18}$

While this may seem to be an appropriate solution, it creates a number of problems. In particular, staff who resign or are even fired are often rehired in other correctional environments, potentially importing their predatory behavior with even more vulnerable populations. Moreover, in the absence of a criminal conviction, it is difficult to flag predatory staff. Agency fears of employee lawsuits for libel or slander, ${ }^{19}$ mean that in practice employers provide little information other than the dates of employment for past employees, giving little notice to others of the reason for termination. Finally, the resignation creates a sense among employers and prosecutors that the matter is resolved. Given the high burden of proof in criminal cases, many prosecutors see this as a just result, failing to realize that prosecution accomplishes other goals - a public recognition that sexual abuse of offenders rises to the level of a crime, that prisoners are victims who deserve their day in court as well, and that no one is above the law.

\section{Inmate-on-Inmate Sexual Abuse}

Most prosecutors, federal and state, who were interviewed and attended focus group meetings, had not tried inmate-on-inmate sexual abuse cases. Federal investigators and prosecutors noted that they may not have seen inmate-oninmate cases because investigation of those incidents in Federal Bureau of Prison (BOP) facilities are handled by the Federal Bureau of Investigations (FBI). Both federal and state prosecu- tors agreed though, that a more likely scenario is that the incidents of inmate-on-inmate sexual abuse are not being reported or are handled administratively. While federal prosecutors stated that they would prosecute a forcible rape case if one was brought to them, none who participated in the focus groups or individuals interviewed had ever done so. ${ }^{20}$

\section{"Consensual" v. Forced Sex}

Another barrier to prosecuting cases of sexual violence in custody is the issue of consent. ${ }^{21}$ The defense of consent is a major factor in the decision to prosecute these cases, according to both federal and state prosecutors. This is true whether the case involves staff sexual abuse of inmates or inmate-oninmate abuse.

\section{Staff Sexual Abuse of Offenders}

All fifty states, the District of Columbia, and the federal government prohibit staff sexual abuse of offenders. ${ }^{22}$ Twenty-five states and the District of Columbia specifically provide that inmates cannot consent to sex with staff. ${ }^{23}$ The large majority of states recognize that staff have tremendous control over every aspect of an offender's custody. That imbalance of power negates consent. However, two states, Nevada and Delaware, have laws which recognize that inmates can consent to sex with staff. In Delaware and Nevada, inmates can be prosecuted for consensual sex with staff members. ${ }^{24}$

Even though statutes, were enacted to address the issue of inmate consent by creating separate crimes for this offense, prosecutors still find it difficult to prosecute these cases. Both state and federal prosecutors noted that while it was easier for juries to understand the abuse of power issue, juries have problems accepting the credibility of inmates. Juries perceived inmates as liars with a bias against corrections staff, as well as having a financial motive for making the allegations. Additionally, prosecutors reported that juries often viewed both male and female inmates as seducers of correctional staff. ${ }^{25}$ Often, both male and female inmates have histories of work in the sex industry, and histories of physical and sexual victimization. ${ }^{26}$ These histories make them more vulnerable to sexual abuse and at the same time more willing to use sex to bargain for better treatment. ${ }^{27}$ For example, in a 2005 Bureau of Justice Statistics (BJS) publication on correctional authorities' reports of sexual violence in custody, correctional agencies classified two-thirds of all staff sexual abuse of inmates as romanti; in 2007, they classified fifty-seven percent of staff sexual abuse of inmates as "appeared willing." 28

\section{Inmate-on-Inmate Sexual Abuse}

Inmate-on-inmate sex in correctional settings presents a different barrier to prosecution. In correctional settings, there is a continuum of sexual behavior between inmates that goes from rape to completely consensual sex. Between those ends of the spectrum are coerced and strategic sex. ${ }^{29}$ Complicating matters, consensual sex today can become forced, coerced or strategic at some other point. In other words, the behavior and the motivation of the parties are not static and often change. This flux in the conduct creates tremendous bar- 
riers to prosecution both in the community and in prison. One federal prosecutor stated that she would be unlikely to prosecute a case of inmate-on-inmate sexual abuse unless there was physical evidence of violence such as injuries or eyewitness testimony. ${ }^{30}$ Prosecutors reported less interest in a case where "consent" is an available defense unless there was also evidence of additional crimes, such as the presence of contraband or the threat of violence.

While consensual sex between inmates may be a conduct code violation punishable administratively, it is generally not a crime. Even in those places where it is a crime, ${ }^{31}$ it is not a high priority for prosecutors. If one offender claims that the sex was consensual, prosecutors complain that they become "he said, she said" cases involving two inmates, both convicted offenders with clear issues of credibility.

\section{Deficiencies in Criminal Laws Prohibiting the Sexual Abuse of Individuals in Custody}

Prior to 1990 , most state and federal jurisdictions did not have laws which specifically prohibited the sexual abuse of individuals under correctional supervision by correctional staff. As a result, few corrections staff could be prosecuted for the sexual abuse of persons in custody. Today, each of the fifty states and the federal government have passed laws making it a crime for correctional staff members to engage in any sexual conduct with a person in custody. ${ }^{32}$

Even after this conduct was criminalized, however, sexual abuse of persons in custody by corrections staff carried relatively lenient sentences compared to sexual assault statutes covering rape in the community. ${ }^{33}$ This was especially true under federal law, where prior to 2006, sexual abuse of a ward was a misdemeanor. ${ }^{34}$ Not surprisingly, federal prosecutors cited low penalties as the primary reason for not prosecuting custodial sexual abuse cases. ${ }^{35}$ Recent amendments to state and federal laws have substantially increased the penalties for sexual abuse of offenders, but it is difficult to determine the effect of these enhancements on prosecution, particularly in the federal system where the changes are so recent and prosecution statistics for these cases have not been studied. ${ }^{36}$

\section{Federal Law}

In April 2005, the Office of Inspector General (OIG) issued a report which found federal laws prohibiting sexual abuse of persons in custody deficient in two respects. First, while the federal law ${ }^{37}$ criminalized all sexual relations or contact between prison staff and offenders, those acts were classified as misdemeanors, and thus punishable by a maximum sentence of one year, unless the conduct involved force or overt threats. Second, the OIG report noted that the federal laws did not apply to employees of contract facilities, ${ }^{38}$ further hampering OIG and federal prosecutors in "obtaining prosecutions" of sexual abuse in those facilities. ${ }^{39}$ Compounding the problem was the fact that state prosecutors often had limited resources which they could focus on prosecuting sexual abuse in correctional facilities at the state level. This lack of resources fore- closed them from prosecuting cases that occurred in private contract facilities which often housed federal inmates.

OIG recommended that federal law be amended to correct these deficiencies. Amendments were passed and became effective on January 5, 2006, making sexual abuse of an offender by corrections staff, absent force or overt threats, a felony punishable by up to five years imprisonment. The amendment also expanded federal jurisdiction to include sexual abuse of federal prisoners housed in private correctional facilities. Another piece of legislation, The Adam Walsh Child Protection and Safety Act, also passed in 2006. This Act increased penalties for the sexual abuse of a minor or ward to fifteen years. ${ }^{40}$

The new legislation should result in more cases involving allegations of sexual abuse in BOP facilities being investigated ${ }^{41}$ and presented to United States Attorney's Offices (USAOs) for prosecution. However, the likelihood of full prosecution on the merits after a case is presented remains to be seen. Still, prosecutors faced with limited resources must consider investing time and resources in cases where victim/witness reliability is an issue and where potential defendants are law enforcement officers who are community members without criminal records. Prosecutors are also concerned about jury and judge appeal for the reasons identified above. The combination of these two factors creates a perceived and real risk that prosecutions will fail. Additionally, sex offender registration requirements, while providing stronger penalties, ${ }^{42}$ also makes judges and juries more reluctant to convict these law enforcement defendants in the absence of exceptionally strong evidence. ${ }^{43}$

\section{State Law}

While all states have criminalized, in some form, the sexual abuse of persons in custody, these laws are not uniform and vary widely. State prosecutors report that often state statutes still do not cover custodial sexual abuse in a number of settings--parole and probation for example. ${ }^{44}$ Some states allow consent as a defense in staff abuse of inmates ${ }^{45}$ and still others impose minimal sanctions. ${ }^{46}$

In some states, prosecutors voiced frustration with their statutory scheme that only made prosecution of sex offenses of persons in custody a misdemeanor. With low maximum penalties, i.e., misdemeanor status, prosecutors believed it signaled that the offense was not serious, or at least not a priority. Others felt it gave them far less bargaining power in plea negotiations. Moreover, in many states, corrections officers cannot be terminated simply because they have a misdemeanor conviction. 47

Some state prosecutors pointed out that other tools such as revoking peace officer certifications or licenses may help. Additionally, they felt that sex offender registration could act as a bargaining chip because fewer people would risk going to trial if they knew they might be required to register as a sex offender if convicted. Ultimately however, state prosecutors agreed with their federal counterparts that, especially in cases of staff sexual misconduct, mandatory sex offender registration 
could hinder successful prosecutions because agencies are more likely to keep incidents in house and because defendants are more likely to go to trial.

\section{Lack of Prosecutorial Experience}

$$
\text { Trying Sex Abuse Cases }
$$

Prosecutors face a number of difficulties proving allegations of sexual abuse of persons under correctional supervision. Prosecutors recognize that sex crimes are among the most difficult cases to prosecute regardless of the status of the victim. Many prosecutors and investigators interviewed for this article articulated the unique difficulties in prosecuting allegations of sexual abuse or assault, whether or not those crimes occurred in institutional settings. They noted that these cases are difficult to prosecute because they rely on many aspects of a good investigation to corroborate the victims' reports including: proper processing of crime scenes; collection and preservation of evidence; knowledge of physical, medical and scientific evidence; prompt reporting and cooperation from the victim; proper interviewing of victims and witnesses; and corroboration of the victim's testimony by other witnesses or physical evidence. Unfortunately, these ingredients are often missing in institutional investigations of custodial sexual abuse.

Prosecutors believe that obtaining a thorough and prompt investigation is more difficult in the corrections environment. This difficulty is compounded by the lack of training that correctional investigators receive in responding to sexual assaults in custody.

Additionally, most states lack staff or units who primarily prosecute sex cases. These cases are often assigned to prosecutors who must take any case that comes to them. Prosecutors who lack experience trying sexual assault cases may not fully understand the dynamics of sexual violence, which is important at every stage of the investigation and prosecution from the first interview with the victim, to crafting opening statements, direct examinations, and closing arguments. Moreover, understanding the dynamics of sexual violence and a jury's possible reaction to the victim or circumstances of a particular case, can inform prosecutors' decisions about cases. Familiarity with forensic evidence, like DNA, and special rules of evidence that apply in sexual assault cases, such as rape shield laws, are also important for successful prosecutions.

One former federal prosecutor illustrated the need for experience and training by describing a case that he tried and lost involving the sexual abuse of a fourteen- year old girl by a corrections official at a halfway house. The prosecutor said that at the time of the trial he was surprised at the loss because he thought the case was strong, but realized in hindsight that his lack of experience trying sexual assault cases led him to misjudge the strength of his evidence and how the jury would view the credibility of the victim. ${ }^{48}$

State prosecutors reported that sex crimes in general require a very specialized knowledge. Even seasoned prosecutors expressed concern that prosecutors know little about corrections institutions making prosecuting sex crimes an even more daunting task. ${ }^{49}$ These cases, according to state prosecutors, require prosecutors to learn an entirely new culture. In some ways, prosecuting sexual abuse of an offender is at odds with prosecutors' culture and belief systems. State prosecutors noted that they spend most of their career sending people to prison, and it is a shift in culture and way of thinking to advocate for offenders by prosecuting their abusers. 50

\section{Trying Cases from Correctional Settings}

Prosecutors and investigators noted that prosecutors are not sufficiently knowledgeable about prisons, prison culture or correctional practices. Federal investigators also felt that prosecutors did not have sufficient knowledge of issues such as the coercive influence of contraband on sex and security in the institution, and admittedly, many prosecutors and investigators have never been inside a correctional facility prior to their involvement in these cases.

One prosecutor, who has seen many cases from her state prison system, said that it took prosecutors in her office some time just to understand the prison's record keeping system. She said that every time they prepared for trial and assured defense counsel and the judge that all documentation from the prison had been provided in discovery, they learned of new documents. Finally, her office learned that the prison kept two sets of records, one for the prison and a second to provide to prosecutors and police. She said that in some cases, they also described crimes in a third set of documents created and maintained by the intelligence branch of the prison. The prosecutor said that until all of the document problems were resolved with the prison, the prosecutors had trouble meeting their discovery obligations in these cases.

\section{Lack of Understanding About the Correctional Environment}

Some corrections administrators and investigators believe that prosecutors do not have a full appreciation of the impact of sexual abuse on inmates. ${ }^{51}$ Sexual abuse of persons in custody violates constitutional rights, creates psychological and emotional trauma, 52 may result in disciplinary actions against the victim, and undermines the safety and security of the institution. ${ }^{53}$

Sexual abuse of persons in custody also undermines the system of security of the institutions because often it is not limited to sexual abuse. Nearly half of the subjects in federal staff sexual misconduct cases also smuggled contraband into prisons for the offenders with whom they had sexual relationships. ${ }^{54}$ Many of these staff members helped offenders conceal contraband by alerting the offenders to unannounced searches or by storing contraband with the staff's possessions. ${ }^{55}$ This quid pro quo relationship for the purpose of engaging in sexual conduct with an inmate compromises safety barriers and subjects the remaining prison population and correctional staff to substantial risk.

\section{Witness Credibility}

Credibility of witnesses is paramount in any sexual assault case. The credibility of an inmate witness in cases of sexual abuse in correctional settings is immediately suspect because of his status as an offender. 
Both state and federal prosecutors have reported that in cases where the only evidence is the victim's report with no corroboration - the case is virtually untriable. Credibility issues that are not supported by physical evidence, corroborated by correctional staff, or have multiple victim incidents become a case of "he said, she said."56 According to prosecutors, the risk of trying these cases is great. The high likelihood of an acquittal may offset the deterrent effects of investigating these cases as well as discourage prompt reporting of sexual assaults for fear of retribution following an acquittal at trial.

Multiple interviews of victims that generally happen in the correctional setting can also have an impact on whether prosecutors accept a case. Inconsistencies in statements and the victim's credibility in general led one federal prosecutor to believe a victim was lying. ${ }^{57}$ That prosecutor indicated that there are many cases of sex between staff and offenders that are not presented to prosecutors because there was often no evidence. In order to corroborate the victim's story, prosecutors want physical evidence and contemporaneous reporting, or the knowledge that the staff member had assaulted more than one offender. 58

Federal prosecutors also agreed that if there is no physical evidence or non-inmate proof of the abuse, they are less likely to take the case generally because of credibility issues with the victim. ${ }^{59}$ Prosecutors admitted that even if they do prosecute, witnesses who are incarcerated are often immediately impeached with past convictions. One prosecutor felt that jurors assess the credibility of a witness from a correctional setting the same way they assess the credibility of any witness, but because they are felons, they are presumed to lack credibility by many jurors and indeed jury instructions direct that jurors may consider previous convictions in assessing credibility. ${ }^{60}$

Recommendations for Improving Prosecutions of Correctional Sex Abuse Cases

\section{Train Prosecutors on the Dynamics of Sexual Abuse in Correctional Settings}

Training prosecutors on techniques for prosecuting custodial sexual abuse cases is critical. Additionally, while it is important to train prosecutors, it is essential to take a team approach and include federal and state level investigators, law enforcement, facility administrators and correctional staff, and victim advocates to have a collaborative effort in understanding the dynamics of prison rape.

The Civil Rights Division of the Department of Justice recommends that U.S. Attorneys team with them in order to train prosecutors on the unique techniques used in sex crimes cases such as the use of a grand jury, interview techniques, and the benefits of having an OIG investigator involved-techniques that are not used in other cases. They suggested curricula that included: (1) correctional culture; (2) prosecuting a sex crime; (3) security implications; (4) understanding sexuality in a correctional setting; (5) corroboration and alternative evidence to DNA; (6) helping judges and juries to sympathize with your victim; and (7) creative tools for prosecution.

Finally, prosecutors and investigators need to understand that investigating and prosecuting custodial sexual abuse cases are important. These prosecutions are essential to maintaining safe, secure and humane institutions and communities. Custodial sexual abuse closely correlates with other issues such as contraband, coercion and use of force. In order to protect other staff and inmates in these environments, it is important to prosecute these cases.

\section{Build Relationships with Others in the Field}

In order to overcome barriers to prosecuting these cases, it is important for correctional officials, investigators and prosecutors to understand each other's roles and challenges. In order to build these relationships, focus group participants recommended forming agency task forces, composed of investigators, prosecutors, correctional staff, law enforcement and victim services.

Specific to federal prosecutions, focus group participants recommended having an investigative agent housed in the U.S. Attorney's Office in order to reduce problems prosecutors have identified in regards to resources - staff time and cost for the prosecutor's office. For state systems, using outside law enforcement can help gain credibility. Many agencies recommend using third-party investigative units in state prisons and local jails. Establishing an investigative protocol that includes outside law enforcement, who often have special sexual assault units, adds credibility to the case because they often bring special skills and resources and are not perceived as allied with correctional agencies.

\section{Amend State and Federal Criminal Law}

Prosecutors have noted deficiencies in both federal and state criminal law in this area. First, prosecutors recommend stronger penalties. Prosecutors feel that misdemeanor sanctions for these offenses are inappropriate for the crime and limit their bargaining power; staff will not accept a plea and inmate defendants will only receive limited penalties in addition to current sentences. On the other hand, especially where correctional officers are concerned, jurors may be reluctant to convict staff members of a felony for sexually abusing inmates.

Additionally, laws need to be amended to cover all personnel in all correctional settings, and provide that inmate consent is not a defense to sexual abuse. Furthermore, correctional administrators should sanction behavior that may not be criminal, but which is sexually abusive - such as inappropriate viewing or photographing of inmates.

\section{Utilize a Variety of Laws as Tools for Prosecuting Sexual Abuse}

Both investigators and prosecutors pointed out that sex cases in prisons do not "sell." Often, only the introduction of other violations - such as contraband, bribery or malfeasance in office-committed by staff members or inmate defendants 
result in convictions. Prosecutors should be encouraged to use all of the tools available to them when prosecuting sexual abuse of persons in custody. Mandatory reporting, obstruction of justice, malfeasance in office, statutory rape, sexual assault and conspiracy are all legal tools which are available to prosecute custodial sexual abuse and surrounding circumstances. In addition, prosecutors could look to loss of license and sex offender registration, as ways to either secure pleas or impose additional sanctions, which ensure that the staff defendant does not secure employment in other institutional settings.

\section{Develop Special Prosecution Units for Sexual Abuse Cases}

In general, federal prosecutors rotate through a variety of assignments, while state prosecutors often prosecute whatever case they are assigned. Federal and state prosecutors recommend having dedicated staff who are familiar with sex cases or having allegations of sexual abuse of a person in custody referred to specialized sex crimes or civil rights units ${ }^{61}$ where they exist. At a minimum, there should be a designated prosecutor in every jurisdiction who is trained and prepared to prosecute these crimes when they occur. Historically, the types of experience and support provided by specialized units has improved the rate of successful prosecution for crimes once considered difficult to prosecute, such as domestic violence, sexual assault, and crimes against children.

\section{Increase Resources for Prosecution of Sexual Abuse}

Federal prosecutors have suggested a resource shift would be most helpful for them. To begin to elevate this issue, federal prosecutors have suggested that an OIG agent be assigned to each USAO, and funds to prosecute cases of sexual violence in institutions be increased. While federal prosecutors recognize that there are staff and budgetary limits, they suggest that moving the resources, both funding and personnel, to offices that have more of these cases, would improve prosecution outcomes.

State prosecutors have stated that the only way to prosecute these cases with any expertise would require an increase of resources. In addition to needed financial support and manpower, state and local prosecutors called for some clarity on the responsibility of prosecuting these cases - are they state cases, federal cases, local cases and who pays for prosecution and who investigates.

\section{Change the Culture of Prosecutors and Judges Regarding Sexual Abuse in Correctional Settings}

Prosecutors agreed that a cultural shift would elevate this issue on the political agenda of many elected prosecutors as well as appointed and elected judges. ${ }^{62}$ Investigators and corrections officials report that the likelihood that a particular case will be prosecuted often has a lot to do with the perception of the individual prosecutor and his or her office about the importance of these cases, especially in relation to the case prosecution priorities in her jurisdiction.

The Attorney General, United States Attorneys, and the heads of state and local prosecutors' offices must send the message to their prosecution staff that sexual abuse of persons in custody will be prosecuted vigorously, and they must provide them with the resources and training to do it.

Conclusion

Prosecutors believe that, in addition to training and resources to improve investigations and prosecutions of allegations, decision makers must have the political will to change prosecutorial and investigative responses to custodial sexual violence. Prosecutors requested that policy makers at the highest levels of government put their authority behind this issue because where the interest of such persons lie, so go the resources. Organizations like Human Rights Watch, ${ }^{63}$ The Commission on Safety and Abuse in America's Prisons, ${ }^{64}$ and a myriad witnesses testifying before the NPREC have echoed this sentiment. 65

$\dagger$ This article relies heavily on the work of current and former state and federal prosecutors, in particular the work of Roy Austin, Diane Berman, Deborah Connor, and Julie Grohovsky. We particularly want to thank Deborah Connor for her feedback and insights on this article. Ms. Connor's deep experience litigating sex offenses and domestic violence offenses was invaluable. In particular, her experience securing a conviction in United States v. Robert White, which involved the sexual assault of a transgendered inmate by a correctional officer, informs this article. We were ably assisted in this endeavor by Julie Grohovsky, a former federal prosecutor who worked for several years in the United States Attorney's Office for the District of Columbia prosecuting domestic violence and sexual assault cases. Ms. Grohovksy also worked in the Office of the Inspector General. Her experience and knowledge were invaluable in making contacts and collecting this information.

1 Prison Rape Elimination Act of 2003 (PREA), 42 U.S.C. $\S \S$ 15601-15609 (2003).

2 See generally The National Institute of Corrections/ Washington College of Law Project on Addressing Prison Rape (NIC/WCL Project), Addressing Staff Sexual Misconduct with Offenders (March 2006), Investigating Allegations of Staff Sexual Misconduct with Offenders (March 2005, 2004), Responding to Inmate - on - Inmate Sexual Violence (March 2007), and Addressing Sexual Abuse of Youth in Custody (July 2007, Nov. 2005), under National Institute of Corrections (NIC) cooperative agreements 01P18G108 through 07S24GJQ1.

3 See NIC/WCL Project, Investigating Allegations of Staff Sexual Misconduct with Offenders, Prosecutor Break Out Sessions (July 9-14, 2006), under NIC Cooperative Agreements 06S20GJJ1 (meeting notes on file with author) [hereinafter 2006 Prosecutor Breakout Sessions]; NIC/WCL Project, Investigating Allegations of Staff Sexual Misconduct with Offenders, Prosecutor Break Out Sessions (July 15-20, 2007), under NIC Cooperative Agreement 07S24GJQ1 (meeting notes on file with author) [hereinafter 2007 Prosecutor Breakout ses- 
sion].

${ }^{4}$ See NIC/WCL Project, Improving Prosecutions of Allegations of Sexual Abuse in Correctional Settings, A Meeting with Federal Prosecutors (Oct, 13, 2006), under NIC Cooperative Agreements 06S20GJJ1 (attendance list on file with author) [hereinafter Federal Meeting]; NIC/WCL Project, Improving Prosecutions of Allegations of Sexual Abuse in Correctional Settings, A Meeting with State Prosecutors (Oct. 27, 2006), under NIC Cooperative Agreements 06S20GJJ1 (attendance list on file with author) [ hereinafter State Meeting].

5 See U.S. Dept. of Justice, Office Of The Inspector General: Deterring Staff Sexual Abuse of Federal INMATES 3 (2005) [hereinafter OIG REPORT] (noting that sexual abuse of female inmates is both underreported and alarmingly prevalent).

6 See The Honorable Kim Worthy, Prosecuting Attorney for Wayne County, Michigan at the Public Hearing Before the National Prison Rape Elimination Commission: Reporting, Investigating and Prosecuting Prison Rape: What is Needed To Make The Process Work? (August 3, 2006), available at http://nprec.us/docs/detroit_testimony_worthy.pdf [hereinafter NPREC Worthy Testimony] (elaborating on why Wayne County is unable to continue to prosecute inmate sexual abuse cases); see also The Honorable Gregory Miller, United States Attorney for the Northern District of Florida at the Public Hearing Before the National Prison Rape Elimination Commission: Reporting, Investigating and Prosecuting Prison Rape: What is Needed To Make The Process Work? (August 3, 2006), available at http://nprec.us/docs/detroit_issues_miller .pdf (discussing the many issues which make it difficult for prosecuting sexual assault within prisons).

7 See Senator Jeff Sessions, Address at the Public Hearing Before the National Prison Rape Elimination Commission: The Cost of Victimization: Why Our Nation Must Confront Prison Rape (June 14, 2005), available at http://nprec.us/docs/ SenatorJeffSessionsRemarks_Vol_1.pdf [hereinafter NPREC Sessions Testimony] (encouraging the criminal justice system to take the problems of incarcerated sexual abuse seriously).

8 See generally Mary De Ming Fan, Disciplining Criminal Justice: The Peril and Promise of Numbers, 26 Yale L, \& PoL. R. 2 (2007) (explaining that the seemingly favorable statistics regarding criminal justice prosecutions do not necessarily signify success).

9 See Rape, Abuse and Incest National Network, Reporting Rates, http://www.rainn.org/get-information/statistics/reporting-rates (last visited Mar. 26, 2008) (finding that if a sexual assault is reported there is a $50.8 \%$ chance of an arrest; if there is an arrest made, there is an $80 \%$ chance of prosecution; and if there is a prosecution there is a $58 \%$ chance of a conviction). Factoring in unreported rapes, only $6 \%$ of sexual assault perpetrators will spend time incarcerated-15 of 16 perpetrators walk free. $I d$.

${ }^{10}$ See NPREC Worthy Testimony, supra note 6 (explaining that in the wake of budgetary constraints, prosecution of crimes between inmates is not a priority for Wayne County).

${ }^{11}$ See Steadman v. S.E.C., 450 U.S. 91 (1981) (finding that in Spring 2008 an administrative proceeding, matters in issue need only be established by a preponderance of the evidence).

12 See Victor v. Nebraska, 511 U.S. 1, 5 (1994) (finding that the standard of proof beyond a reasonable doubt "is an ancient and honored aspect of our criminal justice system").

13 See NPREC Sessions Testimony, supra note 7; see also Glenn Fine, Inspector General, Address at the Public Hearing Before the NPREC: The Cost of Victimization: Why Our Nation Must Confront Prison Rape (June 14, 2005), available at http://www.nprec.us/docs/InspectorGeneralGlennFine_Vol_1.p df (admonishing that the laws criminalizing staff sexual relations with federal inmates are not sufficient).

${ }^{14} \mathrm{Id}$.

${ }^{15} \mathrm{Id}$.

${ }^{16} \mathrm{Id}$.

17 See Garrity v. State of New Jersey, 385 U.S. 493 (1967) (discussing employees' rights against criminal self-incrimination).

18 See Federal Meeting, supra note 4 (discussing that while investigators in general agreed with the need to increase administrative penalties, they complained that more often than not, those were met with opposition by unions).

19 See Robinson v. Robinson, No. 05-CV-01433, 2006 WL 726296 (D. Colo. Mar. 20, 2006) (issues included: malicious prosecution, defamation, 14th Amendment Due Process); Corona v. Lunn, No. 00-CIV-7330, 2002 WL 550963 (S.D.N.Y. Apr. 11, 2002) (issues included: false arrest and malicious prosecution).

20 See Federal Meeting, supra note 4 (noting the lack of experience in prosecuted forcible prison rape cases).

${ }^{21}$ See id.; see also State Meeting, supra note 4 (discussing and indentifying consent as one of the most difficult issues in prosecuting prison rape).

22 Brenda V. Smith, Fifty State Survey of State Criminal Laws, Prohibiting the Sexual Abuse of Individuals Under Custodial Supervision (January 2008), under NIC Cooperative Agreement 07S27GJT7 [hereinafter 50 State Survey].

${ }^{23}$ Id.; see, e.g., Cal. Penal Code $§ 289.6$ (2001) ("Consent by a confined person or parolee to sexual activity proscribed by this section is not a defense to a criminal prosecution for violation of this section."); Fla. StAT. AnN. § 944.35 (2006) (“The consent of the inmate or offender supervised by the department in the community to any act of sexual misconduct may not be raised as a defense to a prosecution under this paragraph."); Wis. Stat. AnN. § 940.225 (West 2005) ("Consent is not an issue in alleged violations ....").

24 See 50 State Survey, supra note 22; see, e.g., Del. Code AnN. tit. $11, \S 1259$ (1995) ("A person is guilty of sexual relations in a detention facility when, being a person in custody at a detention facility or being an employee working at a detention facility, the person engages in sexual intercourse or deviate sexual intercourse on the premises of a detention facility."); NEV. REV. STAT. ANN. § 212.187 (1997) (“A prisoner who is in lawful custody or confinement, other than in the custody of the Division of Parole and Probation of the Department of Public Safety or residential confinement, and who voluntarily engages in sexual conduct with another person is guilty of a category D felony."); 
see also Phillips v. Bird, Dept. of Corrs. of the State of Del., 2003 U.S Dist. LEXIS 22418 (D. Del. Dec. 1, 2003).

25 See Federal Meeting, supra note 4; State Meeting, supra note 4; see also Carrigan v. Davis, 70 F. Supp. 2d 448 (D. Del. 1999).

26 See generally Caroline Harlow, Bureau of Justice Statistics, Prior Abuse Reported By InMATES AND Probationers 1 (1999), available at http://www.ojp.usdoj.gov/ $\mathrm{bjs} / \mathrm{pub} / \mathrm{pdf} /$ parip.pdf (detailing the statistical results of prior sexual abuse in state and federal prisons).

27 See DC Rape Crisis Center, Effects of Sexual Abuse: Internal, http://dcrcc.org/effects.htm (last visited Feb. 6, 2008) (discussing the internal effects of sexual abuse as including: depression, low self-esteem, anger or control issues, anxiety, shame, guilt); Angela Browne \& A.J. Sabree, NIC/WCL Project, Responding to Inmate-on-Inmate Sexual Violence, Presentation on the Impact of Victimization (March 2007), available at http://www.wcl.american.edu/nic/conference_ march_07/modules/11_impact_of_past_victimization.pdf?rd=1 (noting the links between incarceration and victimization); Brenda V. Smith, NIC/WCL Project, Continuum of Sexual Behavior in Institutional Settings (2006), under NIC Cooperative Agreement 06S20GJJ1 (PowerPoint presentation on file with author) [hereinafter Smith, Continuum of Sexual Behavior] (illustrating that strategic sex or sex as a bargaining tool is used).

28 See Allen Beck \& Timothy Hughes, Bureau of Justice Statistics, U.S. Dep't of Justice, Prison Rape Elimination Act: Sexual Violence Reported by Correctional Authorities, 2004, at 9 (2005) [hereinafter BeCK \& Hughes 2004]; see Allen Beck, Paige Harrison and Devon Adams, Bureau of Justice Statistics, U.S. Dep't of Justice, Prison Rape Elimination Act: Sexual Violence Reported by Correctional Authorities, 2006, at 6 (2007) [hereinafter BECK, HARRISON \& AdAMS 2006].

29 See Brenda V. Smith, Rethinking Prison Sex: Self-Expression and Safety, 15 Colum. J. Gender \& L. 185, 225 (2006) [hereinafter Smith, Rethinking Prison Sex] (discussing the continuum of sexual expression in correctional environments the main concern of which is whether the state has an ability to regulate that expression); see also Smith, Continuum of Sexual Behavior, supra note 27 (analyzing (through a visual) the limits placed on prisoners' ability to sexual express themselves).

30 See Federal Meeting, supra note 4.

31 See generally U.S. v. Brewer, 363 F. Supp. 606 (M.D. Pa. 1973); People v. Frazier, 64 Cal. Rptr. 447 (1967); People v. Coulter, 288 N.W.2d 448 (Mich. Ct. App. 1980) (holding the state sodomy law constitutional as applied to sex in prison); George v. Lane, No. 82 C 7084, 1987 U.S. Dist. LEXIS 3659 (N.D. Ill. Apr. 30, 1987) (finding that prison regulations prohibiting consensual sex are constitutional); Johnson v. Johnson, 385 F.3d 503 (5th Cir. 2004); Croom v. Wagner, No. 06-1431, 2006 U.S. Dist. LEXIS 64915 (E.D. Pa. Sept. 11, 2006); Barnes v. Ozmint, 3:04-21836-CMC-JRM, 2005 U.S. Dist. LEXIS 38173 (D.S.C. Nov. 7, 2005); People v. Rollins, 569 N.E.2d 1251 (Ill. App. 1991); U.S. v. Robert White (Criminal Action
No. F130-05, 2006).

32 See 50 State Survey, supra note 22.

33 See, The NiC/WCL Project on Addressing Prison Rape, Investigating Staff Sexual Misconduct with Offenders Training Materials: In the News : Criminal Convictions Chart Staff Sexual Misconduct with Offenders (2007) (illustrating that prosecutions and the sentence received by staff in sexual misconduct cases are relatively low); see also, Rape Abuse and Incest National Network, Reporting Rates, available at http://www.rainn.org/get-information/statistics/reportingrates (last visited March 30, 2008) (providing statistics regarding the reporting and prosecution of sexual assaults).

34 See 18 U.S.C. $\S \S 2243(b), 2244(a)(4), 2244(b)$ (2006) (raising the penalty for sexual abuse of a ward from misdemeanor to felony punishable levels).

35 OIG REPORT, supra note 5, at 8.

36 See Interview with Federal Prosecutor (Feb. 28, 2006) [hereinafter FP Interview] (stating that " $[\mathrm{t}]$ here have not been enough cases since the penalties were enhanced, to make any type of meaningful judgment about the impact the amended law will make on the rate of prosecutions); see also OFFICE OF THE Inspector General, Training: Investigating Allegations of Staff Sexual Misconduct with Offender (June 2006), under NIC cooperative agreement 06S21GJL7.

3718 U.S.C. $\S \S 2241,2243-2244$.

38 OIG REPORT, supra note 5, at 18.

$39 \mathrm{Id}$. at 19.

40 See Adam Walsh Child Protection and Safety Act, Pub. L No. 109-248, 120 Stat 587 (2006) (codified in scattered sections of 18 U.S.C.).

41 Federal investigators are concerned that these amendments may decrease prosecutions due to the increased severity of the sentences. See generally OfFICE OF THE InSPECTOR GenERAL Training: Investigating Allegations of Staff Sexual MisconduCT WITH OFFENDER (June 2006), under NIC cooperative agreement 06S21GJL7.

42 See Smith v. Doe, 538 U.S. 84, 101 (2003) (holding that "[a]lthough the public availability of the information may have a lasting and painful impact on the convicted sex offender, these consequences flow not from the Ac's registration and dissemination provisions, but from the fact of conviction, already a matter of public record. The State makes the facts underlying the offenses and the resulting convictions accessible so members of the public can take the precautions they deem necessary before dealing with the registrant").

43 See Federal Meeting, supra note 4.

44 See State Meeting, supra note 4; see also Brenda V. Smith \& Jaime M. Yarussi, NIC/WCL Project, Breaking the Code of Silence, A Correction Officers' Handbook on Identifying and Addressing Sexual Misconducts 4 (June 2007) [hereinafter CO HANDBOOK] (highlighting that agencies include but are not limited to: jails, lock-ups, prisons, community facilities for adults or juveniles, juvenile detention centers, immigration detention facilities and community corrections agencies including probation, parole, half-way homes, electronic or home monitoring, 
work release, pre-release centers or pre-trial release and contract facilities). Personnel includes but is not limited to: correctional officers, administrators and staff, volunteers, medical and mental health personnel, contract employees and maintenance and food service workers. Id.; see also 50 State Survey, supra note 22 .

45 See 50 State Survey, supra note 22; see also Del. Code AnN. tit. 11, § 1259 (2008); Nev. Rev. StAT. AnN. § 212.187 (LexisNexis 2007).

46 See 50 State Survey, supra note 22 (indicating that while the 46 See 50 State Survey, supra note 22 (indicating that while the vast majority of states define staff sexual misconduct as a felony, some also still only charge it as a misdemeanor or define the crime as a graduated sanction allowing the prosecutor to charge either a misdemeanor or a felony depending on the facts of the case).

47 See State Meeting, supra note 4.

48 NIC/WCL Project, The Role of Prosecutors in Cases of Staff Sexual Conduct with Offenders, Investigating Allegations of Staff Sexual Misconduct with Offenders (July 2005), available at http://www.wcl.american.edu/nic/Training/Curriculum/ July_2005/Prosecution.ppt?rd=1 ("On the day of her testimony, the victim dressed provocatively and giggled nervously. Because of the prosecutor's lack of experience he had not instructed her on how to dress for court, did not ask her questions on direct examination that would help her to explain to the jury why she was giggling and not crying and that in general he felt that he had misjudged the amount of time it would take to prepare her to testify.").

49 See State Meeting, supra note 4.

$50 \mathrm{Id}$.

51 See Federal Meeting, supra note 4; 2006 Prosecutor Breakout Sessions, supra note 3; 2007 Prosecutor Breakout Sessions, supra note 3.

52 See generally Women's Rights Project, Human Rights Watch, All Too Familiar: Sexual Abuse of Women in U.S. State Prisons (1996); Women's Right's Project, Human Rights Watch, Nowhere to Hide: Retaliation Against Women IN Michigan State (1998), available at http:/www.hrw.org/reports98/women/; HuMAN RigHTS WATCH Report, No Escape: Male Rape In U.S. Prisons (2001) [hereinafter No Escape]; AMnEsty InTERnAtional, "Not PART OF My Sentence," Violations of the Human Rights of Women in Custody (1999); Amnesty InT'L, USA: The Findings of A Visit to Valley State Prison for Women, California (1999); AMnesty InT'L, Children AND Women ABused IN Correctional FACILITIES (1998).

53 OIG REPORT, supra note 5, at 7-8; see also CO HANDBOOK, supra note 44 , at 8.

54 See Federal Meeting, supra note 4.

55 OIG REPORT, supra note 5, at 7; see also Chitra Subramanyam, FCI Guard Sentenced for Sex Act, TALlaHASSEE Democrat, Aug. 29, 2006 (noting that in a case in the Federal District Court in Tallahassee, Florida, Bureau of Prison guards were charged with and found guilty of crimes arising out of trading contraband for sex with at least ten offenders). In this same case, an OIG agent was shot and killed at the Federal Correctional Institution in Tallahassee as he and another law enforcement agent were in the process of arresting one of the guards. Id. This is an indication of how such activities can lead to corruption and violence in correctional settings.

56 See Federal Meeting, supra note 4; State Meeting, supra note 4.

57 See FP Interview, supra note 36 (noting that initially the inmate was believed, but that after a thorough investigation it was determined that she was lying). The prosecutor said that the inmate never admitted to lying, but that a "huge amount" of information, including inconsistencies in her statements as well as statements of other prisoners that discredited her version of events and her credibility, generally led prosecutors to believe the inmate was lying. Id.

$58 \mathrm{Id}$.

59 See Federal Meeting, supra note 4.

60 See FP Interview, supra note 36 (stating that because they are felons by virtue of their status as a prisoner, you need to corroborate their testimony).

61 See Federal Meeting, supra note 4 (discussing Washington, DC's prosecution unit and how some specialize in sex crimes). Prosecutors noted that because of the difficulty prosecuting sex crimes, many prosecutors' offices have specialized sex crimes units or at least one or two veteran sex crimes prosecutors who handle these cases. Id. In addition, while state and local prosecutor's offices are more likely to have experience trying these cases, the depth of that experience depends on the number and types of cases that occur in their districts and the resources they are able to devote to those cases. Id.; see also Gina DeBottis, Chief Prosecutor, Special Prosecution Unit, Texas at the Public Hearing Before the National Prison Rape Elimination Commission: Reporting, Investigating and Prosecuting Prison Rape: What is Needed To Make The Process Work? (Aug. 3, 2006), available at http://nprec.us/docs/detroit_issues_debottis.pdf (describing the special sex crimes prosecution unit in Texas and their experience with prison sex cases).

62 CO HANDBOOK, supra note 44, at 7.

63 See No EscAPE, supra note 52, at 68-75.

64 See generally John J. GibBons And Nicholas DE B. Katzenbach, Vera Institute of Justice, Confronting Confinement: A Report of THE COMmission on SAFETy AND Abuse IN AMERICA's PRISONS (2006), available at http://www.wcl.american.edu/nic/documents/4.VERACommis sionReport.pdf?rd=1 (reporting on the violence and abuse in U.S. jail and prisons).

65 See generally National Prison Rape Elimination Commission Hearings, available at http://nprec.us/proceedings.htm (listing the nationwide public hearings which discuss the elimination of prison rape).

Brenda $V$. Smith is a Professor of Law at American University's Washington College of Law and is the Program Director for the National Institute of Corrections Project on Addressing Prison Rape (www.wcl.american.edu/nic) at the Washington College of Law. Additionally, Professor Smith is a commissioner on the National Prison Rape Elimination Commission (www.nprec.us).

Jaime M. Yarussi is the Program Coordinator for the National Institute of Corrections Project on Addressing Prison Rape (www.wcl.american.edu/nic) at the Washington College of Law. 